\title{
An Analysis on the Translation Types of the Electric Cooker's Operating Instruction Labels
}

\author{
Wiwik Puji Rahayu
}

\begin{abstract}
This study is concerned with an analysis on the translation types of the electric cooker's operating instruction labels on Yong $\mathrm{Ma}$, Cosmos, and Maspion, especially an analysis of translation types, deletion of information (loss of information), and structural adjustment (rank-shift). So, the relevant theories were referred and discussed. This research used theoretical framework the translation processes Nida and types of translation Catford to analyzed translation processes and to determined types of translation that are used on electric cooker's operating instruction labels.

The methodology which is used by the researcher in investigating this study is descriptive qualitative. The data will be analyzed by identifying the translation types that are used in the target language texts of electric cooker's operating instruction labels and the translation types that are used in realizing the messages of the source language. The population in this study is the English text and its target language text of electric cooker's operating instruction labels from different trade mark. In this case, the target language is Indonesian.

The result of this study can be briefly stated as follows: From three electric cooker's operating instruction labels that have been analyzed, the researcher found that the number of the target language text were 78 texts, consist of 9 literal translations, 22 free translations, 32 pragmatic translations, and 15 dynamic translations. The result shows that the most of source language texts that are translated using pragmatic translations cause "rank-shift" in those target language texts, while the most of source language texts that are translated using free translations cause deletion of information (loss of information) in those target language texts.
\end{abstract}

Keywords----Analysis, Electric cooker, Labels, Operating instructions, Translation

\section{INTRODUCTION}

Language is the most important means of communication. Therefore, language mastery is absolutely needed in our life, not only in reading, writing, but also understanding information.

English becomes second language in many countries in the world. Because of that fact, mastery English is an absolute thing to do by all of the community. As an international language, English play an important role in the world. It can be used to communicate with people from other countries and

Wiwik Puji Rahayu, is with Communication Department, Social and Politics Science Faculty, Airlangga University, Surabaya - East Java, Indonesia.

Email: wiwik.gonen@gmail.com also used as an instrument of utilizing modern science and technology. One who want to be survives in global era has to master this language well.[5]

Learning a foreign language means learning how to transfer a message from that language to target language through translation activities. Therefore, translation is called as a part of communication, which plays an important role of transferring a source language message idea into target language. In other words, translation is rewriting of an original text into the second language. Translation is really a language activity to produce the same meaning of sentences or text in other language. The activity goes through the process in which the translator has to see events first, the concepts or ideas, the source language to react the event of the target language, which is result in translation (Larson, 1984 : 476).[7]

It is undeniable that most science and technology are invented and spread out from west through words and form instruction expressed in foreign language, especially English. People, especially Indonesian, whose English is not their native language will face difficulties in understanding information written in English because English has different system from Indonesian language.

Based on the problem faced by one whom English is not their native language, translation studies is important to know the differences between English and Indonesian language forms. It will make a translator is easier in translating a message of every instruction written in English. As English becomes the first international language, all of international information can be heard, seen, read and known in English. The rapid development of science and technology influences man's activities. Most activities which used man's power now become easier because it has changed to machine power. It can be seen from the fact that most of home appliances which worked manually have been changed to electrically. As the effect of development of science and technology all operating instructions labels are written in English. So it will lead new problems for people whose English is not their native language. They will face difficulties in understanding messages that are stated in operating instruction labels of every electric tool. Therefore, mastering translation skills are absolutely needed. They have to know some translation types in order to be able to determine which translation types is suitable to define messages in every sentence of operating instruction labels.

For the reason above, the researcher will analyze Translation types in electric cooker's operating instruction labels. The researcher intends to find out how Translations types reflect 
the different messages. By analyzing Translation types, the researcher hopes getting some knowledge in translation, especially Types of Translation and its implementation.

\section{LITERATURE REVIEW}

\section{Translation}

According to Halliday, there is a tendency for mixed languages to get mixed scripts. English is the example. English has been through a great deal of outside influence. After the English overrun Britain, their language was strongly influenced by the native Celtic languages -hardly at all in vocabulary, but quite considerably in some aspects in its grammar. Next it was successively invaded by Norwegian, Danish, and Norman French; then in the renaissance, it took over massive doses of Latin and Greek, not only lexical roots but also large numbers of affixes and the morphological processes that went with them.[6]

There are some definitions of translation. Brislin (1976) defines that translation is the general term referring to the transfer of the thoughts and ideas from one language (SL) to another (TL) whether the language is written or in spoken form [3]. More complete definition stated by Susan Basnett (1991:5) "What is generally understood as translation involves the rendering of a source language (SL) text into the target language (TL), so as to ensure that (1) the surface meaning of both language will be approximately similar and (2) the structure of source language will be seriously distorted".[2]

Another definition of translation stated by Newmark (1981) "a craft consisting in the attempt to replace a written message and or a statement in one language by the same message from the SL into the receptor language, and language that is done in translation can be written or spoken". The result of translation is also the written message of statement in another language, a process of substituting a text in one language or a text in another language. In fact, the translation process does not deal only with linguistic theory but also other knowledge in many fields. If a translation process focuses only on linguistic theory it usually bends to maintain the form of language of the original text.[8]

From the definition stated by linguistics, it can draw a conclusion that translation is a process of transferring thoughts and messages from SL to TL in the form of written and spoken. The meaning of this that has to be transferred, while the form or the style.

\section{Process of Translation}

The process of translation can be defined as the activity of translation. The translation process is often used by a translator as guidance in translating a text from a source language into a target language. Nida (1975:87), illustrated the process of translation make covers three steps, namely analysis, transfer and restructuring.[9]
The Process of translation can be drawn in the following diagrams:

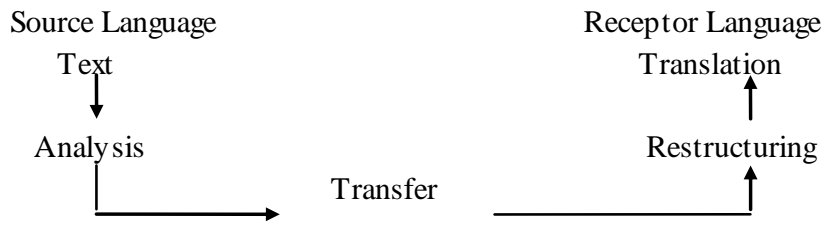

Fig. 1 The Process of translation, Source (Nida, 1975 : 87)

From the diagram the process of translation stated by Nida, it can be seen that is a process in translating a text. First, a translator faces a text written in the SL and then he tries to understand the content of the text. In addition to the point, he has to understand the meaning, or message found in the text. After that he has to transfer the meaning into the target language. He should remember that in this part he has to convey the message exactly without any changes in meaning. So, the meaning of the source language is equivalent to the meaning of the target language. The last work of a translator is that has to restructure the translation into naturalness.

In addition, according to Larson (1984:476), translation has been represented as a process which begins with the source text, analysis this text into semantic structure, and then restructures this semantic structure into appropriate receptor language text. This is the very general way of looking at the translation process. Translation is actually much more complicated than such an overview might indicate. In actual practice, the translator move back and forth from the source text to the receptor text.[7]

\section{Types of translation}

Catford (1980) introduces some terms of translation [4]. They are:

a. Word - for - word translation

Word - for - word translation is a translation based on the arrangement of word in the source language. This kind of translation is very useful to know the form and the arrangement of words in source language line by line without study it earlier.

\section{b. Literal translation}

Literal translation is a traditional translation which transfer the SL text into the TL, without paying attention to the specific characteristic of the target language is awkward. It is formally started by translating wor for word translation but then is to adjust to the grammar of the TL.

c. Free translation

Free translation is translation which conveys the meaning or messages of the source language by reveal on the translator's own words. This type of translation is not only restricted of finding out the equivalence of word, phrase or sentences.

d. Idiomatic translation 
Idiomatic translation is transferring meaning from one language to another by tries to maintain the meaning rather than the form of the source language, and paying no attention to the specific characteristic of the target language. It is sometimes called "dynamic equivalence" which uses natural form of the target language, both the grammatical structure and the choice of equivalence. Idiomatic translation is very useful to know the meaning, information and the message of source language. For example is the English sentences "They eat like a horse" it can be translated into Indonesia "Mereka makan dengan lahapnya".

\section{e. Pragmatic translation}

Pragmatic translation is transferring the meaning from one language to another by tries to maintain the information rather than the form of the source language.

\section{f. Esthetic-poetic Translation}

Estetic-poetic translation is different from pracmatic translation. In esthetic-poetic translation, the translator does not only pay attention to the information, but also to the impression, emotion, and feel within the beauty of the target language. On the other hands, esthetic-poetic translation is called literature translation, such as: poetry translation and prose translation.

\section{g. Ethnography Translation}

In ethnography translation, the translator explains the source language culture to the target language. For example is the difference in using the word "yes" and "yea" in American English. The translator must be able to find the comparison word in target language. This activity will be difficult to do if the source language doesn't have the comparison word in target language. In this case, the translator must give information the meaning of that word.

\section{h. Linguistic Translation}

Linguistic translation is translation which may consist of implicit linguistic information of source language to be explicit one in target language. In linguistic translation, we find out linguistic information, such as: morpheme, word, phrase, clause, and sentences.

i. Communicative Translation

According to Newmark (1981:62), translation is basically a means of communication or a manner of addressing one or more person in the speaker presence.

j. Dynamic Translation

Dynamic Translation is called natural translation. This translation uses the natural form of the target language, both the grammatical structure and the choice of equivalence. Dynamic translation is very useful to know the meaning, information and the message of the source language.

\section{Problems of equivalence}

The problems of equivalence may occur at various levels, ranging from word to textual level. The equivalence problems emerge due to semantic, socio-cultural, and grammatical differences between the source language and the target language. These three areas of equivalence problems are intertwined with one another. The meaning(s) that a word refers to are culturally bound, and in most cases the meaning(s) of a word can only be understood through it context of use. Due to semantic, socio-cultural, grammatical differences between the source language and the target language, loss and addition information in translation cannot be avoided. Bassnett (1991:30) states that once the principle is accepted that sameness cannot exist between two languages, it is possible to approach the question of loss and gain the translation process.[2]. While according to Nida (1975:27), all types of translation involve loss of information, additional of information, and skewing of information.[9]

\section{Additional information}

Information which is not present in the source language text may be added to the target language text. According to Newmark (1988:91), information added to the translation is normally cultural (accounting for the differences between SL and TL culture), technical (relating to the topic), or linguistic (explaining wayward use of word). The additional information may be put in the text (i.e. by putting in the brackets) or out of the text (i.e. by using a footnote or annotation).[8] Such additional information is regarded as an extra explanation of culture-specific concept (Baker, 1992).[1] Additional of information for specification purposes is also required if ambiguity occurs in the receptor language formation and if the fact that greater specificity may be required so as to avoid misleading reference (Nida, 1964:227).[9]

\section{Deletion of information (loss information)}

Baker (1992:40) refers to Deletion as "omission of a lexical item due to grammatical or semantic patterns of the receptor language. She states further that this strategy may sound rather drastic, but in fact it does no harm to omit translating a word or expression in some contexts. If the meaning conveyed by a particular item or expression is not vital enough to the development of the text to justify distracting the reader with lengthy explanations, translators can and often do simply omit translating the word or expression in question.[1]. There are cases where omission is required to avoid redundancy and awkwardness (Nida 1964:228) and this strategy is particularly applied if the source language tends be redundant language. The category of plural in English is both morphologically conditioned (e.g. child/children, mouse/mice), and phonologically conditioned (e.g. book/books, box/boxes, pen/pens). In some circumstances, a plural noun is also preceded by a determiner showing plurality (some books, three pens).[9]

\section{Structural adjustment (rank shift)}

Structural adjustment is another important strategy for achieving equivalence. Structural adjustment which also 
called shift or alteration refers to a change in the grammar form of SL to TL. Structural adjustment, according to Nida (1964:226), has various purposes, including: to permit adjustment of the form of the message to the recruitments of structure of the receptor language, to produce semantically equivalent structures, to provide equivalent stylistic appropriateness, to carry an equivalent communication load.[9] Newmark (1988:85-87) divides the shift of form into four types. One type of shift is the change from singular to plural or in the position of adjective. The position of an adjective in English, for example, may occur before a noun (i.e. a difficult text) or before and after a noun (i.e. a difficult text available in the library). An adjective in Indonesian always comes before a noun. Therefore, a difficult text and a difficult text available in the library should be translated into "sebuah text sulit". Second type of shift is required when a SL grammatical structure doesn't exist in the TL. In English, for example cohesive devices such as "however" and "nevertheless" may be put at the beginning or in the middle of a sentence. The third type of shift is the one where "literal translation" is grammatically possible but may not accord with natural usage in the TL. The English sentence "The man to whom she is talking on the phone lives in Jakarta" can be translated literally into "Laki-laki kepada siapa dia sedang berbicara di telepon tinggal di Jakarta". This literal translation is accurate in content but doesn't sound Indonesian. To conform to natural usage in Indonesian, the structure of the sentence should be adjusted into "Laki-laki yang sedang berbicara dengannya di telepon tinggal di Jakarta", (Newmark, 1988:87). The fourth type of transposition is the replacement of a virtual lexical gap by a grammatical structure.[8]

\section{Methodology}

This study belongs to descriptive study since it just collects and analyses the data taken from electric cookers' operating instruction labels of different Trade Mark. In this research, the instrument used by the researcher is documentation in the form of some electric cooker's operating instruction labels from different Trade Mark.

The population of this study is the English text and its Target Language text of operating instruction labels from different Trade Mark. In this case, the target language is Indonesian. In this research, the sample of this study is English text and its target language text that is Indonesian from three operating instruction labels which have been collected by the researcher from different Trade Mark. They are Cosmos, Maspion, and Yong Ma. In order to study more effectively, the writer focuses on translation type of the target language text.

Techniques of Data Analysis in this study as follows: Reading the sentences in electric cooker's operating instruction labels, classifying the written English text and its target language text in electric cookers' operating instruction labels, choosing three electric cookers' operating instruction labels, and identifying the translation types on the electric cooker's operating instruction labels.

\section{RESUlTS}

There are four translation types found in electric cooker's operating instruction labels that have been analyzed. They are literal translation, free translation, dynamic translation, and pragmatic translation. The writer also wants to explain whether there are or not additional information, deletion of information (loss of information), or structural adjustment (rank shift) in the target language text.

\section{Literal Translation}

In the target language text of those three electric cooker operating instruction labels the researcher found some literal translation. The instruction below found on electric cooker Cosmos.

\section{SL: How to use}

TL: Cara menggunakan

Through analyzing the target language text in Cosmos cooker's instruction labels above, the translation type found by the writer is "literal translation". By translating word for word translation, the source language above will be "Bagaimana untuk menggunakan". Then the translator tries to adjust to the grammar of the target language. So the source language above will be translated into "Cara menggunakan". The conjunction "to" in the source language is not translated into target language text, so it causes "loss conjunction" in the translation above.

\section{Free translation}

In the target language text of the electric cooker's operating instruction labels has been analyzed by the writer, there are 22 Free translation found. The translator uses varieties of free translation. He uses his own words to transfer the meaning of the source language. Most of them cause "loss of information" in the translation, and the rest of them cause "rank shift".

SL: Separate the steam cap from the lid of the product.

TL: Lepaskan Pressure Multi Cap dari penutup. (an instruction on Yong Ma)

The translator uses his own words to translate the source language text above. The word "Separate" which means "Pisahkan" is translated into "Lepaskan" in order to make the naturalness of the target language. The phrase "of the product" in the source language above is not translated, this causes (loss of information) in the target language. In other cases the translator also uses free translation.

\section{Pragmatic translation}

In three electric cooker's operating instruction labels that have been analyzed, the writer finds 32 texts which use this translation type with the various types. In the text below the translator tries to maintain the information meant by the source language:

SL: Exact amount of rice ought to be poured.

TL: Takarlah jumlah beras yang akan digunakan dengan tepat .1 takaran beras adalah isi beras sampai garis $\mathbf{1 6 0}$ pada gelas takaran.

The translator translates not only the form of the source language, but also the information of the source language. 
The sentence "1 takaran beras adalah isi beras sampai garis 160 pada gelas takaran" in the bold type in the target language text above is information meant by the source language. The additional information aims to carry an equivalent communication load. This causes structural adjustment or "rank shift" in translation.

\section{Dynamic translation}

In electric cooker's operating instruction labels that have been analyzed, the writer finds 15 dynamic translation. The translator uses this type of translation to provide equivalent appropriateness. In other words, dynamic translation attempts to convey the thought expressed in the source language (if necessary, at the expense of literalness, original word order, the source text grammatical voice, etc). This type of translation represents emphasis, respectively, on readability and on literal fidelity to the source language text. The text "Don't touch steam vent hole during cooking" in the source language text on Yong $\mathrm{Ma}$ operation steps above is translated into the text "Selama memasak, jangan menyentuh lubang ventilasi uap". The translator chooses the appropriate equivalence to transfer the message and information of the source language. The translator uses the natural form of the target language, both the grammatical structure and the choice of equivalence. It means that this translation type represents emphasis, respectively, on readability and on literal fidelity to the source language text. The content of text on the source language above is transferred to the natural form of the source language.

\section{DISCUSSION}

There are eleven translate on types stated by linguists, but in electric cooker's operating instruction labels that have been analyzed, the writer only found four of them. They are Pragmatic translation, dynamic translation, free translation, and literal translation. The data will be analyzed to determine the translation types that are used on electric rice cooker Yong $\mathrm{Ma}, \mathrm{Cosmos}$, and Maspion. The data is analyzed through the cross language -equivalence. The writer describes the translation types toward cross language-equivalence using descriptive method. From three electric cooker's operating instruction labels that have been analyzed, the writer finds that the number of target language texts is 78 texts. The translation types of those texts consist of 9 literal translations, 22 free translations, 32 pragmatic translations, and 15 dynamic translations. Most of instruction texts that are translated using pragmatic translation cause rank - shift in the target language text, while most of instruction texts that are translated using free translation cause loss in the target language text.

In every electric cooker's operating instruction labels uses different translation type to transfer the message of the source language. In electric cooker Yong $\mathrm{Ma}$, the common translation types that are used are pragmatic translation type to transfer the message of the source language. In electric cooker Yong $\mathrm{Ma}$, the common translation types that are used are pragmatic translation, and in electric cooker Cosmos, the most common translation types used on the instructions are pragmatic translation, while in electric cooker Maspion, the most common translation type used are free translation. It shows that most of the instruction texts use pragmatic translation because this type of translation is transferring the message from one language to another by tries to maintain the information rather than the form of the source language. In every part of instruction is always found pragmatic translation because this type of translation is the most suitable translation type to transfer the message of the source language. The second common translation type that is used is free translation. This type of translation is transferring the meaning of the source language by using the translator own words.

\section{CONCLUSION AND SUGGESTION}

Based on the result of the study above, the conclusion of the study as follows: Most of electric cooker's operating instruction labels using pragmatic translation and dynamic translation to transfer the messages so that the electric cooker's user are easier to understand the information of the products. Most of source language texts that are translated using pragmatic translation cause "rank shift" in those target language text, while the most of source language text that are translated using free translation cause "loss" in those target language texts.

Instruction labels, as an important guidance in operating tools, should give balance information and the information should be easy to be understood, so that the product user will be clearly informed about the product, so determining the appropriate translation types is absolutely needed.

\section{REFERENCES}

[1] Baker, Mona.1992. In Other Words. London and New York: Rout ledge.

[2] Bassnett, Susan. 1991. Translation Studies. London and New York: Routledge.

[3] Brislin, R.W. 1976. Translation: Application and Research. New York : Gardner Press. Inc.

[4] Catford, J.C. 1980. A Linguistic Theory of Translation. London: Oxford University.

[5] Departemen Pendidikan Dan Kebudayaan. 1975. Jakarta

[6] Halliday, M.A.K. 1988. Spoken and Written Language. Victoria: Deakin University.

[7] Larson, Mildred L.1984. Meaning-Based Translation; A Guide to Cross- Language Equivalence. Boston: University Press of America, Inc.

[8] Newmark, Peter. 1988. A Textbook of Translation. London: Prentice Hall International (UK) Ltd.

[9] Nida, Eugene A.1975. Language Structure and Translation. California: Stanford University Press. 